\title{
O ESTRANGEIRO NA CONTEMPORANEIDADE: O RECONHECIMENTO DO OUTRO SOB A ÓTICA DO DIREITO FRATERNO
}

\section{THE FOREIGNER IN THE CONTEMPORARY SOCIETY: THE RECOGNITION ON THE OTHER THROUGH THE PERSPECTIVE OF THE FRATERNAL LAW}

\author{
Florisbal de Souza Del`Olmo \\ Pós-Doutor em Direito (UFSC), Doutor em Direito (UFRGS), Mestre (UFSC) e \\ Especialista em Direito. Especialista em Educação. Professor do Programa de Mestrado e \\ Doutorado em Direito da URI, Santo Ângelo, RS. Líder do Grupo de Pesquisa registrado \\ no CNPq Tutela dos Direitos e sua Efetividade. Coordenador do Projeto de Pesquisa \\ Direito Internacional do Trabalho e o resgate da dignidade e da cidadania. \\ E-mail: florisbaldelolmo@gmail.com
}

\section{Charlise Paula Colet Gimenez}

Doutora em Direito e Mestre em Direito pela Universidade de Santa Cruz do Sul UNISC. Especialista em Direito Penal e Processo Penal pela Universidade Regional do Noroeste do Estado do Rio Grande do Sul - UNIJUÍ. Professora dos Cursos de Mestrado e Graduação em Direito da Universidade Regional Integrada do Alto Uruguai e Missões URI, campus Santo Ângelo. Coordenadora do Curso de Graduação em Direito da URI. Líder do Grupo de Pesquisa Conflito, Cidadania e Direitos Humanos, registrado no CNPQ. Advogada. Atua no estudo do Crime, Violência, Conflito e Formas de Tratamento de Conflitos - conciliação, mediação, arbitragem e justiça restaurativa. E-mail: charliseg@ santoangelo.uri.br

\section{Marsal Cordeiro Machado}

Graduado em Direito pela Universidade Regional Integrada do Alto Uruguai e das Missões - URI, Santo Ângelo/RS. Mestrando em Direito pela Universidade Regional Integrada do Alto Uruguai e das Missões - URI, Santo Ângelo/RS. Participante do Grupo de Pesquisa registrado no CNPq Tutela dos Direitos e sua Efetividade. Servidor do Ministério Público Federal. E-mail: marsal_cordeiro@ hotmail.com

Recebido em: 26/06/2017

Aprovado em: 02/10/2017

Doi: $10.5585 / \mathrm{rdb} . v 18 \mathrm{i} 7.746$

RESUMO: Os novos desafios da sociedade contemporânea, marcada pela fragilidade do Estado nacional e pela legitimação do império da globalização, intensificam o rechaço à periferia da estrutura social, acentuada pelo diferente, o qual, no presente estudo, é retratado no estrangeiro. Tem-se, portanto, o imigrante como representante do risco, justificando, desse modo, a lógica de exclusão, o que produz novos conflitos e vítimas da precariedade. Assim, o presente artigo tem por objetivo abordar o estrangeiro na contemporaneidade a partir do estudo do Direito Fraterno. Para tanto, adota-se o método de abordagem dedutivo, enquanto método de procedimento experimental e histórico. Compreende-se, a partir do retratado descrito, a necessidade de reforçar na sociedade, na relação entre as pessoas, a reabertura dos canais de comunicação interrompidos, permitindo, assim, a (re)construção de laços socialmente destruídos, com o redirecionamento 
para a comunicação, a amizade, a alteridade e a fraternidade. O Direito Fraterno fomenta o reconhecimento do outro e valoriza o ser humano na busca por uma sociedade baseada na paz e na fraternidade, a partir da justiça social e do pacto entre iguais.

Palavras-Chave: Estrangeiro. Reconhecimento do Outro. Direitos Humanos. Direito Fraterno. Alteridade.

ABSTRACT: The new challenges faced by the contemporary society, which is marked by the fragility of the national State and the legitimacy of the empire of globalization, intensify the peripherys's rejection of the social structure, accentuated by the different, which, in the present study, is portrayed as the foreigner. The immigrant represents the risk, justifying the logic of exclusion, which produces new conflicts and victims of precariousness. Thus, the present article aims to approach the foreigner in the contemporary world from the study of Fraternal Law. For this, it adopted the deductive method of approach and the socio-analytical method of procedure. It is understood, from the portrayed described, the need to reinforce in society, in the relationship between people, the reopening of interrupted communication channels, $t$ allowing the (re) construction of socially destroyed links, with the redirection to the communication, friendship, otherness and fraternity. Fraternal Law fosters the recognition of the other and values the human being in the search for a society based on peace and fraternity through social justice and equality. Key-words: Foreigner; Recognition of the Other; Human Rights; Fraternal Law; Otherness.

SUMÁRIO: Introdução. 1. Movimentos migratórios na contemporaneidade: o rompimento das fronteiras nacionais e a produção do estrangeiro. 2. Nacional versus estrangeiro: um olhar dos Direitos Humanos. 3. O reconhecimento do outro pela alteridade do Direito Fraterno. Considerações finais. Referências.

\section{INTRODUÇÃO}

Muito embora migrantes, refugiados e pessoas destituídas de qualquer nacionalidade (os anacionais, mais conhecidos por apátridas) constituam categorias distintas de sujeitos ou de grupos minoritários vulneráveis, o presente estudo refere-se genericamente a eles pelo elemento em comum que os evidencia, isto é, as características da mobilidade e do deslocamento, notadamente para locais diversos do de sua origem. Assim, os termos acima citados por vezes se confundem no decorrer do texto.

A presença dessa minoria, na medida em que reflete o rosto mais conspícuo do processo de globalização e da mudança social que ele desencadeia, tem, por outro lado, ocasionado sublevação de algumas comunidades/líderes políticos, que se mobilizam para disseminar a exclusão, a suspeição, o ódio e a hostilidade, quando deveriam cultivar a fraternidade, o reconhecimento do outro, a cooperação, o cosmopolitismo e o respeito entre os povos. $\mathrm{O}$ acordo e o diálogo são sempre os melhores destinos porque funcionam como semeadura para o futuro - e ninguém sabe como ele será. No entanto, o cenário de hoje está inundado pela discriminação, que, por sua vez, ocasiona o conflito e até problemas de ordem pública.

Apesar de ser uma ocorrência secular, o processo em que pessoas deixam o seu país de origem para outro, buscando (na maioria das vezes) melhores condições de vida, tem se intensificado significativamente, apresentando novas faces e entendimentos complexos. É cediço que a ninguém foi oportunizado escolher nascer somente em locais prósperos e pacificados, mas todos estão embebidos para construir um propósito comum que traga benefícios para toda humanidade.

O recorte do presente estudo passa, em um primeiro momento, por abordar aspectos da globalização, considerado um processo histórico e social impactante, que altera substancialmente o quebra-cabeça político, econômico, social e cultural do mundo, potencializando os fluxos

Revista de Direito Brasileira | São Paulo, SP | v. 18 | n. 7 | p. 422 - 438 |Set./Dez. 2017 
migratórios. O deslocamento de pessoas entre nações ganha força e intensidade, países que anteriormente eram distantes - quase inalcançáveis - hodiernamente se avizinham, haja vista que as distâncias foram (e continuam sendo!) encurtadas.

Na segunda parte, o enfoque se volta à condição do estrangeiro e do nacional, encaixada no tratamento dispensado pelo olhar dos Direitos Humanos num contexto de uma necessária interpretação sistemática a atentar para os princípios da dignidade da pessoa humana e da igualdade, ambos, albergados nos diplomas internacionais.

Em seguida, insere-se o Direito Fraterno, o qual coincide com os Direitos Humanos, com uma consciência a mais: a afirmação de que a humanidade é o lugar comum onde possam ser pensados e reconhecidos os Direitos Humanos. É sob a perspectiva fraterna que há um processo de autorresponsabilização e a superação da rivalidade "irmãos inimigos" para a inclusão do amigo da humanidade, cuja existência pressupõe a universalidade dos Direitos Humanos e a comunhão de pactos entre os seres humanos com suas histórias e suas diferenças.

Para o desenvolvimento da pesquisa, adota-se o método de abordagem dedutivo, eis que o método dedutivo se propõe que antes da observação para a formulação da resposta ao problema, as ideias sejam pensadas, razão pela qual se apresenta a hipótese científica inicial, qual seja, o Direito Fraterno como instrumento de reconhecimento e inclusão do outro que, neste estudo, delimita-se ao estrangeiro. O método de procedimento é experimental, pois o objeto ora estudado foi colocado em condições ideais, a partir das quais foi selecionada a hipótese a ser verifica. Ademais, também é histórico porque se acompanha a evolução a evolução do objeto estrangeiro - ao longo da história.

\section{MOVIMENTOS MIGRATÓRIOS NA CONTEMPORANEIDADE: O ROMPIMENTO DAS FRONTEIRAS NACIONAIS E A PRODUÇÃO DO ESTRANGEIRO}

A observação da história em retrospecto permite enxergar que o movimento migratório, embora não realizado com frequência e raramente ultrapassando regiões muito extensas, de forma alguma é um fenômeno recente, uma vez que se confunde com a própria história da humanidade. Inexiste país ou região do mundo que não tenha "recebido" uma parcela de migrantes, assim como inexiste povo que não tenha sido influenciado, direta ou indiretamente, por incontáveis fluxos migratórios ao longo de sua formação.

Mesmo antes da formação e criação do que se intitula civilização, já havia algumas construções discursivas, tais como na $A$ República de Platão ${ }^{1}$ ou na Política ${ }^{2}$ de Aristóteles, indicando a mobilidade como um problema específico de governabilidade. Na mesma linha, a narrativa bíblica ${ }^{3}$ trata a mobilidade humana como uma saga sem-fim, seja de modo objetivo e temporal, seja de modo transcendente, uma vez que a terra prometida está em outro lugar, longe de onde se está; é preciso mover-se, peregrinar-se, pois é na mobilidade que a fé se prova (SANTOS; LUCAS, 2016, p. 11-13).

Em período anterior à Revolução Industrial, as migrações também contribuíram para que a Europa medieval fosse povoada, sendo um elemento importante da vida econômica europeia, haja vista os deslocamentos nas áreas rurais, de acordo com os ciclos agrícolas, o comércio

1 Livro IV da República. Diálogo travado entre Adimanto, irmão de Platão, e Sócrates, mais especificamente no fragmento 423, consta, a partir de uma fala de Sócrates, conselhos ao príncipe quanto ao modo de se comportar, de exercer o poder, de ser aceito e respeitado pelos súditos, foram razões e meios de administrar a população para estabilizá-la em um determinado espaço (SANTOS; LUCAS, 2016, p. 12-13).

2 No livro IV da Política, especificamente no parágrafo $3^{\circ}$ do Capítulo "Teoria Geral da Cidade Perfeita", ao discorrer acerca da extensão que deve ter uma cidade-estado, Aristóteles dedica especial atenção ao problema da população (SANTOS; LUCAS, 2016, p. 12).

3 Em Êxodo, 23:9, está clara a recomendação de que estrangeiros e peregrinos deste tempo humano são todos irmãos e concidadãos na família de Deus: "Também não oprimirás o estrangeiro; pois vós conheceis o coração do estrangeiro, pois fostes estrangeiros na terra do Egito" (SANTOS; LUCAS, 2016, p. 13).

Revista de Direito Brasileira | São Paulo, SP | v. 18 | n. 7 | p. 422 - 438 | Set./Dez. 2017 
realizado, ou o recurso às migrações como meio de escapar de perseguições religiosas ou políticas (FARIA, 2015, p. 116).

Ao longo dos tempos, esses movimentos foram se intensificando em nível mundial e em meados do século XIX, até a Primeira Guerra Mundial, ocorreu, segundo Brzozowski (2012), uma agudização dos movimentos populacionais no quadro mundial, de modo que nos anos de 1815-1930, aproximadamente 52 milhões de europeus cruzaram o Atlântico e desembarcaram nas Américas, sendo um fator decisivo para o estabelecimento e construção de identidades e mesclas culturais, bem como para conquistar o "Novo Mundo".

Nesse sentido, se os textos antigos, assim como a aparição do Estado moderno, dedicaram um lugar especial para questões relacionadas ao estrangeiro é porque o problema da mobilidade humana - guardadas as proporções - era suficientemente importante para constituir as práticas sociais do seu tempo, o que demonstra que os fluxos migratórios ao longo da história não são fatos isolados e esporádicos, mas que (des)construíram e (de)marcaram a sociedade tal como é conhecida.

A mobilidade de pessoas sempre existiu e continua a existir em diversas comunidades do mundo inteiro. Dia após dia, no cenário da expansão cada vez mais intensa dos países e das aflições, agitações e enfrentamentos ocasionados por ela, pessoas abandonam (in)voluntariamente seu local de origem em busca de dignidade e vão estabelecer-se noutras regiões. Existem, assim, inúmeros processos que tiveram distintos fundamentos ideológicos e teóricos, de modo que variadas lógicas orientaram suas estratégias e estabeleceram seus objetivos (SANTOS, 2016, p. 63-64), sendo a movimentação de pessoas, pois, "uma característica intrínseca do ser humano, que tem a necessidade de movimentar-se constantemente, deslocandose no espaço" (MAZZUOLI, 2011, p. 709).

Com efeito, embora as perspectivas históricas demonstrem que o fenômeno migratório está na gênese da existência humana, bem como se trata um aspecto de mudança social, o objeto deste artigo é discutir esse movimento de pessoas, a partir da globalização, a qual, segundo Anthony Giddens (2010, p. 28), está sacudindo o modo de vida atual. Não se trata de uma ordem global conduzida por uma vontade humana coletiva, mas que está emergindo de uma maneira anárquica, fortuita, trazida por uma mistura de influências, a qual não é firme nem segura. Ao contrário, eivada de ansiedades, bem como marcada por profundas divisões.

De acordo com Galli (2010, p. 41), "la era global es de hecho una nueva dimensión magmática de lo real, precisamente la 'movilización global', caracterizada por la presencia conjunta de multiplicidades espaciales temporales, donde nada ni nadie es y a lo mismo que antes". Em outras palavras, com o processo de globalização, tudo

se desterritorializa e reterritorializa. Não somente muda de lugar, desenraiza-se circulando pelo espaço, atravessando montanhas e desertos, mares e oceanos, línguas e religiões, culturas e civilizações. As fronteiras são abolidas ou tornamse irrelevantes ou inócuas, fragmentam-se e mudam de figura, parecem, mas não são" (IANNI, 1996, p. 169-0).

Com todas suas nuances e facetas, a globalização tornou ainda mais cristalina a movimentação de pessoas, sobretudo a partir do final do século $\mathrm{XX}$, quando o processo é acelerado devido ao impulso e desenvolvimento da tecnologia nos setores de transporte e comunicações. A "globalização, tal como a estamos experimentando, é sob muitos aspectos não só nova, mas também revolucionária" (GIDDENS, 2010, p. 20), não sendo caracterizada como "um processo singular, mas um conjunto complexo de fatores" (GIDDENS, 2010, p. 23).

Os contatos entre os países distantes na era contemporânea multiplicaram-se, possibilitando, de um lado, maior relacionamento entre os povos com culturas diferentes, de outro, desafiando práticas consolidadas e interpretações sedimentadas. Integração e homogeneização; diferenciação e integração são, nessa perspectiva, dois lados de uma só face. As

Revista de Direito Brasileira | São Paulo, SP | v. 18 | n. 7 | p. 422 - 438 |Set./Dez. 2017 
mesmas relações e forças que promovem a integração suscitam o antagonismo, já que elas sempre deparam diversidades, alteridades, desigualdades, tensões, contradições (IANNI, 2002, p. 30).

Uma vez facilitado o processo de mobilidade, comprime-se o tempo e o espaço, de modo que se intensificam as relações, e se alimentam a diversidade de expectativas e a multiplicidade dos modos de ser (IANNI, 2002, p. 30), gerando efeitos nas esferas econômica, cultural, política e social dos países envolvidos, sendo esse entrelaçamento inevitável. Por mais distante que o lugar seja, ocorre o rompimento de suas fronteiras e ele poderá ser de algum modo acessado, pois

vivemos num mundo de transformações, que afetam quase todos os aspectos do que fazemos. Para o bem ou para o mal, estamos sendo impelidos rumo a uma ordem global que ninguém compreende plenamente, mas cujos efeitos se fazem sentir sobre todos nós (GIDDENS, 2010, p. 17).

A informação, especialmente obtida por meio da rede mundial de computadores, sobre condições de vida melhores em outro lugar tendem a proporcionar expectativas que antes não eram vistas em sociedades até então isoladas - não há dúvidas de que viver em países desenvolvidos da Europa é mais atrativo do que viver em países em conflitos armados no Oriente Médio -, também contribui e alavanca substancialmente os processos de deslocamentos, passando a envolver "distintas áreas territoriais e comunidades humanas do planeta, em uma dimensão que nunca antes havia sido vista ou concebida" (SANTOS, 2016, p. 63). Nesse contexto, o

"nosso modo de vida moderno" inclui a produção de "pessoas redundantes" (localmente "inúteis", excessivas ou não empregáveis, em razão do progresso econômico; ou localmente intoleráveis, rejeitadas por agitações, conflitos ou dissensões causados por transformações sociais/políticas e subsequentes lutas por poder) (BAUMAN, 2017, p. 9).

A novidade do fenômeno migratório na contemporaneidade deve-se ao seu aspecto global, à magnitude de pessoas e países envolvidos e à crescente importância do assunto visando à formulação de políticas nacionais e internacionais para fomentar o reconhecimento e valorização do ser humano por meio do Direito Fraterno a fim de alcançar uma sociedade baseada na paz e na fraternidade, a partir da justiça social e do pacto entre iguais, uma vez que "as migrações são, assim, aspecto central da globalização, componente integral de espaços globais, que se tornaram interdependentes" (FARIA, 2015, p. 49).

De acordo com a Organização Internacional para Migrações (OIM), estima-se que existem 232 milhões de migrantes em todo o mundo, ${ }^{4}$ o equivalente a $3 \%$ da população mundial. Em termos percentuais, segundo a Comissão Global sobre Migrações Internacionais, se verifica que o crescimento no número de migrantes internacionais apresenta certa estabilidade (aumentou de $3 \%$ da população global, em 2005, para 3,1\%, em 2010). No entanto, em números absolutos o contingente de deslocamentos atuais é elevado, sendo resultado de um crescimento acelerado no número de migrantes a partir dos últimos 30 (trinta) anos do século XX: em 1970, existiam 82

4 OIM. World Migration Report 2015, Migrants and Cities: New Partnerships to Manage Mobility. Genebra: OIM, 2015. O Relatório Mundial da Migração visa informar como o processo migratório vem moldando as cidades e como a vida dos migrantes é moldada pelas cidades. Além disso, contribui para o debate sobre migração de três maneiras: a) leva inquérito de migração para o nível da cidade e ajuda melhorar a compreensão das economias políticas locais de migração e desenvolvimento urbano; b) chama a atenção para o sustento dos migrantes nas cidades do Sul Global; c) analisa a migração interna e internacional (tradução livre). Disponível em: < https://www.iom.int/world-migrationreport-2015> Acesso em: 09 ago. 2017. 
milhões de migrantes; esse número alcançou 175 milhões, em 2000, e cerca de 200 milhões em 2005. ${ }^{5}$ Na metade do século XXI, estima-se que o número de migrantes internacionais chegará a 405 milhões. $^{6}$

Mais que números, isso reflete as tentativas humanas de corrigir as mazelas sociais, as dificuldades demográficas, as catástrofes ambientais e a crise de paz que a humanidade enfrenta. A imigração é, nesse sentido, a única opção. Criam-se oportunidades de ser, agir, viver, pensar, sonhar.

As causas que levam homens, mulheres, crianças e idosos a se movimentarem e abandonarem seu local de origem têm uma multiplicidade de fatores, podendo - raríssimos casos - acontecer para buscar uma qualificação acadêmica e profissional. Ou - esmagadora maioria dos casos - em razão das relações familiares, tragédias naturais, perseguições religiosas e políticas e, também, devido ao desrespeito aos direitos humanos e fundamentais dos países de origem, são alguns dos exemplos que impulsionam as pessoas a buscarem uma vida diferente no Estado que as recebe. Em outras palavras, "o imigrante contemporâneo precisa mover-se para não sucumbir e para manter-se vivo. É mais uma tentativa de preservação do que qualquer outra coisa" (LUCAS, 2016, p. 94).

O resultado dessa dinâmica nem sempre é positivo, aliás, o local escolhido para se ter uma vida mais digna nem sempre é alcançado, sobretudo se o destino for países europeus e os Estados Unidos da América. O que inicialmente é considerado um sonho para os migrantes que buscam uma condição de vida melhor, no percurso vira pesadelo, quiçá, tragédia, visto que esse grupo minoritário enfrenta incontáveis perigos, como o tráfico de pessoas, embarcações lotadas e em condições pouco navegáveis, cercas de arames farpados, muros apressadamente erguidos e campos de refugiados, para citar alguns exemplos. A luz, dessarte, vem acompanhada da sombra, sendo, não raras vezes, a escuridão o destino final.

Conforme o relatório "Jornadas Fatais: Rastreando Vidas Perdidas durante a Imigração, apresentado no ano de 2014 pela International Organization for Migration (OIM), ${ }^{8}$ estima-se que pelo menos 4.077 migrantes morreram naquele ano tentando entrar em outro território, um aumento de $70 \%$ em relação a todo o ano de 2013, que contabilizou 2.400 vítimas. Desde a virada do milênio, calcula-se que 40.000 migrantes tiveram suas vidas interrompidas durante as jornadas de peregrinação - em busca da terra prometida!?.

As perigosas rotas de imigração do Mar Mediterrâneo respondem por grande parte das vidas ceifadas: 3.072, o equivalente a 75\%. Em seguida estão o leste da África, com 251 mortes; a fronteira entre o México e os Estados Unidos, com 230 mortes; e o Golfo de Bengala, no Oceano Índico, com 205 mortes.

A Europa é o destino mais perigoso para imigrantes ilegais. Mais de 22 mil pessoas morreram desde 2000, sendo 4.000 entre os anos de 2013-2014. Apesar do perigo, cresce o número de imigrantes que cruzam o Mar Mediterrâneo em busca de abrigo em solo europeu. $\mathrm{O}$ relatório relembra a morte de 360 imigrantes africanos provenientes da Eritreia e da Somália, em outubro de 2013, que naufragaram ao tentar alcançar a Ilha de Lampedusa, na Itália. A fronteira

\footnotetext{
${ }^{5}$ COMISSÃO GLOBAL SOBRE MIGRAÇÕES INTERNACIONAIS. Migration in Interconnected World: new directions for action. Genebra: CGMI, 2005. Disponível em: 〈http://www.gcim.org/> Acesso em: 09 ago. 2017.

${ }^{6}$ OIM. World Migration Report 2015, Migrants and Cities: New Partnerships to Manage Mobility. Genebra: OIM, 2015. Disponível em: 〈https://www.iom.int/world-migration-report-2015> Acesso em: 09 ago. 2017.

7 Tradução livre.

80 Fatal Journeys Trackink. Live Lostduring Migration é um relatório produzido pela International Organization for Migration (OIM), que examina dados estatísticos coletados junto a governos e organizações não governamentais (ONGs). Os dados, pondera o relatório, podem estar incompletos devido a mortes não computadas oficialmente pelos atores envolvidos. Apesar disso, alguns especialistas sugerem que, para cada cadáver descoberto, existem pelo menos dois outros que nunca são encontrados. Disponível em: <https://publications.iom.int/system/files/pdf/fataljourneys countingtheuncounted.pdf> Acesso em: 09 ago. 2017.
} 
entre México e Estados Unidos também é citada no relatório como uma região crítica, onde 6 mil imigrantes perderam a vida desde 2000, tentando entrar ilegalmente no país norte-americano.

No ano de 2015 a imagem do menino sírio Aylan Kurdi, de apenas 03 anos de idade, encontrado morto numa praia da Turquia virou símbolo da crise migratória que já matou milhares de pessoas em todo o planeta. A fotografia comoveu o mundo e foi veiculada em diversos canais da imprensa internacional, ${ }^{9}$ que a destacaram como a representação mais dura de uma rotina de mortes que sistematicamente vem ocorrendo há anos.

A iminência de perder a vida é renegada ao segundo plano para quem busca apenas manter-se vivo; se deparar com a morte é visto como uma opção mais viável do que continuar a vida sem perspectivas e sentido, mesmo sem saber se concluirão os trajetos e chegarão ao local de destino eles se arriscam.

A simbologia da fotografia do menino sírio e os números de migrantes mortos apontados pelo relatório Fatal Journeys Trackink Live Lostduring Migration no limiar do terceiro milênio são mencionados, não porque sejam fatos únicos e irrepetíveis - a não ser, óbvia e infelizmente, pelas (in)contáveis vidas que se perderam!!! Mas sim porque, por mais dolorida que a realidade e o contexto sejam, são fatos corriqueiros que ilustram o atual cenário de vulnerabilidade que esse grupo minoritário enfrenta, eis que para eles "qualquer outro lugar promete mais do que permanecer onde se está. Não há sentido em ficar, há risco em mover-se e há incertezas quando se chega, caso isso de fato aconteça" (LUCAS, 2016, p. 99).

O problema, contudo, não cessa com os perigos de morte enfrentados durante a jornada. Com sorte, os estrangeiros chegam ao local de destino, à terra prometida, quando, frequentemente, um olhar de suspeita lhes é dirigido, uma vez que "o encontro com o diferente e seu estranhamento marcam a mobilidade urbana e os movimentos migratórios" (SANTOS; LUCAS, 2016, p. 22).

Embora o deslocamento para além das fronteiras de uma população apresente traços positivos, representando um saldo social e econômico por meio da agregação de valores, além de construir o seu espaço, fundando novos tempos e mundos, bem como interagindo com as diferenças (LUCAS, 2016, p. 96), o aspecto negativo, alicerçado no ultrapassado "emblema da sociedade nacional simbolizada no estado-nação" (IANNI, 1996, p. 87), traduz-se na forma violenta do Estado que procura manter a coesão e a ordem dentro do seu território e a integração da população local, uma vez que

afixar o rótulo de "valor humano inferior" a outro grupo é uma das armas usadas pelos grupos superiores nas disputas de poder, como meio de manter sua superioridade social. Nessa situação, o estigma social imposto pelo grupo mais poderoso ao menos poderoso costuma penetrar na autoimagem deste último e, com isso, enfraquecê-lo e desarmá-lo (ELIAS; SCOTSON, 2000, p. 24).

Países que apresentam melhores condições materiais de vida de maneira alguma estão dispostos a abrir suas fronteiras e construir pontes para receber os estrangeiros. Ao contrário, fecham suas portas e constroem muros para dificultar ou até mesmo impedir a sua entrada. Assim, em oposição aos fluxos migratórios e aos câmbios culturais, fomentam ideias de

9 "Se estas imagens com poder extraordinário de uma criança síria morta levada a uma praia não mudarem as atitudes da Europa com relação aos refugiados, o que mudará?", questiona o jornal britânico "Independent". Disponível em: <http://www.independent.co.uk/> Acesso em: 09 ago. 2017; "The Guardian", outro jornal britânico, disse que as fotos levaram para as casas das pessoas "todo o horror da tragédia humana que vem acontecendo no litoral da Europa". Disponível em: <https://www.theguardian.com/international> Acesso em: 09 ago. 2017; O americano "Washington Post" classificou a imagem de "o mais trágico símbolo da crise de refugiados do Mediterrâneo”. Disponível em: < https://www.washingtonpost.com/: Acesso em: 09 ago. 2017. 
separação e defesa da identidade nacional, bem como políticas de controle, seleção e discriminação do processo migratório.

Esse é o paradoxo vivido atualmente. De acordo com Bauman (1997, p. 27),

para habitantes do Primeiro Mundo, as fronteiras dos Estados foram derrubadas, como foram as mercadorias, o capital e as finanças. Para os habitantes do Segundo Mundo, os muros constituídos pelos controles de imigração, as leis de residência, a política de "ruas limpas" e "tolerância zero" ficaram mais altos; os fossos que os separam dos locais de desejo e da sonhada redenção ficaram mais profundos, ao passo que todas as pontes, assim que se tenta atravessá-las, revelaram-se pontes levadiças [...], são adulados e seduzidos a viajar, sempre recebidos com sorriso e de braços abertos. Os segundos viajam às escondidas, muitas vezes ilegalmente, às vezes pagando por uma terceira classe superlotada, ainda por cima são olhados com desaprovação, quando não presos e deportados ao chegarem.

Além disso, o medo conduz esse dilema. Em uma obra recente, Bauman sinaliza que "estranhos em nosso meio" aparecem o tempo todo e assombram todos os setores da população com uma intensidade e num grau mais ou menos semelhante. Sabe-se muito pouco para se alcançar a capacidade de interpretar seus artifícios e compor as respostas adequadas - adivinhar quais possam ser suas intenções e o que farão em seguida, sendo a ignorância quanto a como proceder, como enfrentar uma situação desconhecida uma das causas de ansiedade e medo (2017, p. 14). Estrangeiros são vistos facilmente como marginais. Suas identidades ficam num estado de clivagem, em uma certa esquizofrenia cultural (MENEZES, 2007, p. 119), sendo interpretados e confundidos por conservadores como terroristas, como um risco que gera instabilidade e, portanto, precisa ser evitado.

É a partir desse cenário concreto que as representações e os estereótipos são desenvolvidos sobre a imagem do estrangeiro. Inventou-se o estranho, o estrangeiro, inimigo, a ameaça que vem de fora e que deve lá ser mantida ou que está dentro e deve ser eliminada, jogando-a para fora, uma vez que tal grupo minoritário é o portador daquilo que o nacional não é, por isso a sua presença desafia (LUCAS, 2016, p. 95), o que causa inquietação e medo perante a visão dos recém-chegados sem teto, provocando animosidade em relação a eles e estímulo a violência, e também ao (mau) uso ou abuso de sua condição visivelmente empobrecida, trágica e vulnerável (BAUMAN, 2017, p. 16).

A imagem do estrangeiro é eivada de ambivalências: ao tempo em que se aproximam fisicamente estão distantes afetiva e emocionalmente; ao tempo que em que são incluídos estão excluídos; ao tempo em que apresentam identidade e traços culturais próprios que os caracterizam, estratégias voltadas ao conservadorismo, à tradição local e à imutabilidade ganham força; ao tempo em que trazem em sua bagagem sonhos e expectativas de uma vida com maior dignidade, são (des)constituídos como ameaça e problema à segurança nacional, sendo, por isso, malquisto pela população e também pelo Estado.

Nessa ótica, Tedesco (2010, p. 30), citando o autor italiano Perrone, afirma "que a relação com o estrangeiro suscita contemporaneamente fascínio e medo da diversidade, atração pela novidade e temor pela instabilidade e a precariedade que o novo pode provocar". O rechaço ao outro e a naturalização do estranho crescem quando o tema migratório é manipulado pela mídia para "denunciar" que os Países de primeiro mundo estão sendo "invadidos", de modo que o impacto das notícias veiculadas chega a causar, segundo Bauman, um verdadeiro "pânico moral". Para o autor,

os noticiários da TV, as manchetes do jornal, os discursos políticos e os tuítes da internet, usados para transmitir focos e escoadouros das ansiedades e dos 
temores do público, estão atualmente sobrecarregados de referências à "crise migratória" - que aparentemente estaria afundando a Europa e sinalizando o colapso e a dissolução do modo de vida que conhecemos, praticamos e cultivamos. Essa crise é hoje uma espécie de codinome politicamente correto para a fase atual da eterna batalha dos formadores de opinião pela conquista e subordinação das mentes e sentimentos humanos $(2017$, p. 7$)$.

Da mesma forma, quando a questão migratória ganha corpo no terreno político, mais espinhoso é o caminho da integração para os estrangeiros. Políticas nacionais de controle de fronteiras, aliadas aos inflamados discursos anti-imigrações, buscam responsabilizá-los pela crise econômica internacional. Exemplos retrógrados de xenofobia e preconceito não faltam.

$\mathrm{Na}$ recente campanha eleitoral para a presidência da França, a candidata da Frente Nacional, Marine Le Pen, adotou em seu discurso uma plataforma nacionalista e anti-imigração. Há, ainda, a figura de Donald Trump, que venceu a corrida presidencial norte-americana alicerçado em um discurso contrário à presença de imigrantes no território dos EUA. Conceitos antes consolidados sobre os benefícios da migração vêm sendo questionados e passam a informar o debate político contemporâneo. É o retrocesso em países que tinham o multiculturalismo como emblema da integração positiva dos migrantes na sociedade autóctone (FARIA, 2015, p.40).

Em razão disso, considerando-se a entrada de estrangeiros um fenômeno crescente, o Estado receptor necessita moldar-se à transnacionalidade, estabelecendo claras políticas de gestão da imigração e seus impactos nas esferas jurídica, econômica, social e cultural para acolhê-los de maneira eficaz e, assim, construir uma comunidade global menos dividida e mais multicultural e cosmopolita, a fim de que a vida deles, indistintamente, seja uma vida embebida de sentidos, condição que tem sido negada para muitos.

\section{NACIONAL VERSUS ESTRANGEIRO: um olhar dos Direitos Humanos}

A dicotomia entre nacionais e estrangeiros e o problema relacionado à diferença não é uma questão atinente ao final do século XX e início do século XXI, uma vez que

a diferença e sua inclusão em distintas ordens discursivas sempre existiu, ainda que em boa parte da história da humanidade suas mazelas tenham sido invisibilizadas. O que há, nas últimas décadas, em termos de novidade em relação a isso, é um processo de exponencialização da sua visibilidade e o caráter libertador que as narrativas sobre a diferença assumiram (SANTOS; LUCAS, 2015, p. 30).

Nessa vertente, viu-se que o aumento de estrangeiros vem gerando certas animosidades entre os nacionais do país receptor, as quais podem ser traduzidas pelas dificuldades de incluí-los no interior de um espaço público que até então não lhes pertencia, bem como pela negação e acesso a direitos fundamentais básicos. Diante disso,

o mundo dos excluídos cresce diante dos nossos olhos diariamente, pessoas que não são capazes de permanecer na sociedade ativa flutuam às suas margens ou têm o sentimento de terem sido expulsas, descartadas. Para elas, as portas da democracia fundada em trabalho e direitos estão fechadas. Mesmo que estivessem abertas, seriam as portas do fundo, que só levariam aos andares inferiores, sem escadaria para o crescimento social. Pior que isso, o uso dessas escadarias é prerrogativa exclusiva dos outros, um instrumento de discriminação, um mecanismo de privilégio. E assim a tensão positiva que mantém a sociedade em equilíbrio é perturbada (BAUMAN; MAURO, 2016, p. 47). 
Assim, com base no atual contexto de dificuldades de convívio harmonioso e recíproco entre nacionais e estrangeiros, é necessário mirar o olhar à pauta dos Direitos Humanos, eis que

à medida que os direitos humanos são definidos em relação a qualquer indivíduo, onde quer que se encontre, no tempo e no espaço, e que são direitos exigíveis de qualquer Estado, fazer discriminação em razão de origem nacional, passa a ser a negação da universalidade da pessoa humana (SOARES, 2004).

A internacionalização dos Direitos Humanos, fenômeno emergente após as atrocidades realizadas durante a Segunda Guerra Mundial, possibilitou o alargamento de horizontes dos direitos fundamentais, no conteúdo e na abrangência territorial, de modo que nunca na história universal os direitos fundamentais cumpriram uma função tão viva, nuclear e inspiradora do funcionamento global do ordenamento jurídico, quanto na contemporaneidade. Chegou-se ao entendimento de que a própria humanidade, como um todo solidário, deve respeito integral aos direitos humanos (COMPARATO, 1999, p. 45).

Com a maior integração da sociedade mundial, os problemas relacionados aos direitos humanos e fundamentais, de acordo com Marcelo Neves (2013), tornaram-se insuscetíveis de serem analisados por uma única ordem jurídica estatal no âmbito do respectivo território, sendo, nesse contexto, necessária uma relação transversal permanente entre ordens jurídicas distintas em torno de problemas comuns, como é o caso dos movimentos migratórios.

O regime que versa sobre os Direitos Humanos é um cardápio jurídico sólido o bastante para que a comunidade internacional formule ações visando à proteção dos estrangeiros, eis que se posiciona em direção à afirmação de sua maior positividade e eficácia (BOBBIO, 1992). Assim, "o ideal de Direitos Humanos nasce, nessa conformidade, integrado pela noção de proteção à pessoa enquanto ser humano e pelo pressuposto de dignidade" (CALETTI; STAFFEN, 2017, p. 99).

As normativas relacionadas aos Direitos Humanos, notadamente a Declaração Americana dos Direitos e Deveres do Homem, a Declaração Universal de Direitos Humanos de 1948, o Pacto Internacional de Direitos Civis e Políticos de 1966, assim como o Pacto Internacional de Direitos Econômicos, Sociais e Culturais, também de 1966, foram desenvolvidas "com base na ideia de que a adesão a padrões de justiça compartilhados é condição para a participação no Estado na sociedade moderna internacional" (FARIA, 2015, p. 179), de modo que a existência de diversos atos normativos fazendo referência aos mesmos direitos serve para reforçar sua importância e a busca por mecanismos complementares (SOARES, 2004).

É a partir daí que se definem os direitos dos estrangeiros/migrantes. A propósito, a Declaração Universal de Direitos Humanos, em seus artigos inaugurais, deixou assentada a proibição geral contra a discriminação ao afirmar que:

Artigo $1^{\circ}$. Todas as pessoas nascem livres e iguais em dignidade e direitos. São dotadas de razão e consciência e devem agir em relação umas às outras com espírito de fraternidade.

Artigo $2^{\circ}$. Toda pessoa tem capacidade para gozar os direitos e as liberdades estabelecidas nesta Declaração, sem distinção de qualquer espécie, seja de raça, cor, sexo, língua, religião, opinião política ou de outra natureza, origem nacional ou social, riqueza, nascimento, ou qualquer outra condição.

Não será tampouco feita qualquer distinção fundada na condição política, jurídica ou internacional do país ou território a que pertença uma pessoa, quer se trate de um território independente, sob tutela, sem governo próprio, quer sujeito a qualquer outra limitação de soberania. 
Com base em tais dispositivos, fica vedada a discriminação e a distinção entre nacionais e estrangeiros, rechaçando-se toda e qualquer expressão que inclua os cidadãos, e exclua os demais. Entretanto, observa-se que a evolução da sociedade não tornou mais dóceis e humanas as técnicas bélicas, ao contrário, as torna mais cruéis e insuportáveis.

A rivalidade e a inimizade estão inseridas dentro de cada um. "O "si mesmo" da humanidade é o lugar daquela ambivalência emotiva que edifica e destrói, que ama e odeia, que vive da solidariedade e de prepotências, de exércitos e de hospitais, de amizade e de inimizades, tudo ao mesmo tempo e no mesmo local" (RESTA, 2004, p. 41). Insere-se, nesse sentido, o questionamento de Albert Einstein a Sigmund Freud, do "por que a guerra?", datado de 1932, no intervalo entre as guerras mundiais - porém tão atual para a época presente -, respondendo-lhe Freud (2005, p. 42-47) que o homem possui um instinto de ódio e de destruição, o que coopera com os esforços dos mercadores da guerra. De fato, não há maneira de eliminar totalmente os impulsos agressivos do homem, porém pode-se buscar desviá-los de forma que não necessitem encontrar expressão na guerra.

Nesse sentido, tudo o que favorece o estreitamento dos vínculos emocionais entre os homens, é antídoto à guerra. Pode ser nas relações semelhantes àquelas relativas a um objeto amado, ou vínculo emocional é o que utiliza a identificação. Ao finalizar a sua carta-resposta, Freud manifesta que também, como Einstein, reage à guerra porque toda pessoa tem direito à própria vida, porque a guerra põe fim a vidas plenas de esperanças, conduz homens a situações humilhantes, compele a matar uns aos outros, e destrói objetos materiais preciosos, produzidos pelo trabalho da humanidade.

A guerra se constitui na oposição à atitude psíquica incutida pelo processo de civilização, e por essa razão não se pode evitar de se rebelar contra ela. Os pacifistas têm uma intolerância constitucional à guerra, porém, pode ser utópico esperar dentro de um espaço curto de tempo que o restante da humanidade ponha fim à ameaça de guerra. Tudo o que estimula o crescimento da civilização trabalha simultaneamente contra a guerra. Tem-se, portanto, que ser homens não corresponde ao fato de ter humanidade (RESTA, 2004), o que corrobora as dificuldades encontradas não somente em receber o estrangeiro, mas em rotulá-lo e distanciá-lo por ser o diferente.

Receber o outro e incluí-lo exige ser amigo da humanidade, ou seja, requer a tomada de posição e o agrupamento em favor de um destino comum. Ao contrário do filantropo, o amigo da humanidade "endereça sua amizade a uma ideia, um projeto, no qual conta o respeito por qualquer outro, e, assim, por si mesmo. A amizade pela humanidade é sensibilidade estética [...], mas é, sobretudo, dever e responsabilidade [...]" (RESTA, 2004, p. 40).

Desafia-se, desse modo, a amizade pela humanidade, alicerçada na superação das ambivalências emotivas e na escolha do universalismo para a sobrevivência do todo. Assim,

Amigo da humanidade é, portanto, o indivíduo moral e racional que, conscientemente, conhece os riscos, mas, gandhianamente, aposta na existência de um bem comum, que é o bem da humanidade em si mesmo. Paradoxalmente, amigo da humanidade é quem compartilha o sentido de humanidade e dela se sente parte, assumindo, também, a existência do inimigo; não o demoniza, nem o descarta, jogando-o em "outro" mundo, mas assume inteiramente o seu problema. A rivalidade reside, portanto, em nós mesmos, dentro da própria humanidade; assim, o amigo da humanidade não é simplesmente o oposto do inimigo, mas é algo diverso que, graças à sua diversidade, é capaz de superar o caráter paranoico da oposição (RESTA, 2004, p. 50).

Nessa ótica, importa eleger um discurso de racionalidade em defesa da paz. Por isso, compreende-se que a metateoria do Direito Fraterno possibilita novas perspectivas para a 
sociedade pós-moderna, utilizando a fraternidade como elo das relações sociais na defesa dos Direitos Humanos e da humanidade como lugar comum.

\section{O RECONHECIMENTO DO OUTRO PELA ALTERIDADE DO DIREITO FRATERNO}

Uma sociedade, para ser realmente humana, não pode renunciar à fraternidade, o que não significa colocá-la em confronto com a liberdade e igualdade, ${ }^{10}$ mas de articular a coexistência das três. Compreende-se, nesse sentido, que a fraternidade poderá desempenhar um papel político se interpretar e transformar o mundo real, revelando um valor heurístico e uma eficácia prática. Se eliminada no cenário social, a fraternidade pode ser resgatada como meio de possibilitar o reconhecimento do outro e de sua alteridade. Tem-se, portanto, o desafio ${ }^{11}$ de "superar a lógica meramente identitária, e caminhar em direção a um reconhecimento efetivo e eficaz da alteridade, da diversidade e da reciprocidade (SPENGLER, 2012).

A palavra fraternidade, de origem do vocábulo latino frater, significa irmão, e no seu derivado fraternitas, fraternitatis e fraternitate. Trata-se de um substantivo feminino, cujo significado é apresentado em quatro sentidos: por parentesco de irmãos ou irmãs; união fraternal; amor ao próximo; e boa inteligência entre os homens, harmonia. Desses significados, compreende-se que a fraternidade se caracteriza por um bom e harmônico convívio entre os seres humanos, na união de ideias e esforços e na boa convivência em comunidade. "Daí inicia-se uma primeira ideia do que venha a ser o Direito Fraterno: é um direito que é para todos e que é aceito e/ou proposto por todos" (STURZA; MARTINI, 2016, p. 995).

Uma sociedade fraterna aposta na própria humanidade, cuja aposta está na existência de um bem comum, ao mesmo tempo em que assume a existência do inimigo, não pelo seu descarte ou colocando-o à margem, mas pelo reconhecimento de que a rivalidade existe dentro de cada um, dentro da própria humanidade. O próprio Direito deve voltar-se ao desenvolvimento humano universal e superar a lógica individualista, a lógica do interesse pessoal, de grupo, de classe ou de etnia, ou seja, o Direito deve adotar "a lógica do "humano" do "estar com o outro" e não "contra o outro" (SPENGLER, 2012).

O Direito Fraterno é um tema constituído de anacronismo, eis que a fraternidade, um dos lemas da Revolução Francesa, ressurge não somente com a necessidade de ser incluída no debate, mas de ser concretizada. Trata-se de um direito jurado em conjunto por irmãos, homens e mulheres, os quais, em união, convencionam as regras basilares de sua convivência. Para tanto, a linguagem jurídica precisa estar ao alcance de todos, isto é, pertencer a todos (RESTA, 2004).

Esse é um direito, outrossim, desvinculado da obsessão da identidade e de espaços territoriais, que determinam quem é cidadão e quem não o é. Ele não se fundamenta em um ethnos que inclui e exclui, mas em uma comunidade, na qual as pessoas compartilham sem diferenças, porque respeitam todas as diferenças (STURZA; MARTINI, 2016, p. 996).

Fundamenta-se o Direito Fraterno como uma nova possibilidade de olhar e estabelecer relações na sociedade por meio de um modelo no qual a Justiça não seja a aplicação de regras

\footnotetext{
${ }^{10}$ Ressalta-se que a fraternidade encontra-se somada à liberdade e à igualdade na Revolução Francesa, o que demonstra que a presença de uma não exclui as demais.

${ }^{11}$ Nesse sentido, adiciona Spengler (2012, p. 90-91) que "cada ser humano nasce num determinado lugar geográfico e social, e isso implica a assimilação de determinada língua, cultura e "maneira de ser no mundo", que faz com que ele se torne o que é. O homem, com efeito, não nasce homem, mas se faz homem. É impossível renunciar a essa identidade originária, que faz parte da nossa condição humana, enquanto seres não totalmente predeterminados pela natureza. Ela se constrói necessariamente num confronto intersubjetivo entre um eu e um outro, e entre nós e os outros [...]".
}

Revista de Direito Brasileira | São Paulo, SP | v. 18 | n. 7 | p. 422 - 438 |Set./Dez. 2017 
frias, mas esteja atrelada a uma moral compartilhada entre iguais, ou seja, um modelo de sociedade na qual a amizade seja entendida como relação pessoal e como forma de solidariedade. O Direito, possuindo como base a fraternidade, constitui-se em um mecanismo de promoção dos direitos humanos, ${ }^{12}$ pois

[...] O olhar vai para a humanidade como um "lugar comum", e não como a abstração que confunde tudo e mascara as diferenças. Os direitos humanos têm uma dimensão "ecológica", são espaço no qual as duplas opositivas são novamente compreendidas: isto nos leva à conscientização de que os direitos humanos podem ser ameaçados sempre e somente pela própria humanidade; mas podem ser tutelados sempre e somente pela própria humanidade (RESTA, 2004, p. 134).

A proposta do Direito Fraterno, defendida por Eligio Resta (2004), se revela como uma nova possibilidade de olhar e estabelecer relações na sociedade, razão pela qual "trata-se de um modelo de direito que abandona a fronteira fechada da cidadania e olha em direção à nova forma de cosmopolitismo que não é representada pelos mercados, mas pela necessidade universalista de respeito aos direitos humanos que vai se impondo ao egoísmo" daqueles que governam ou decidem sob a ótica individualista. Cultivam-se, portanto, as expectativas cognitivas ao invés de arrogância normativa. A seu turno, Spengler (2012, p. 45) complementa que o Direito Fraterno "é aquele que quando a igualdade rompe no coração da soberania parece finalmente realizar um projeto simbólico nascido com a modernidade, aquele do abatimento de um direito paterno, existente desde sempre, dado por Deus, da tradição, da natureza".

Dessa maneira, verifica-se que o Direito Fraterno se constitui em um mecanismo de promoção dos direitos humanos, ao passo que valoriza o homem na sua relação com iguais, bem como as pessoas compartilham sem diferenças, porque respeitam todas elas, daí porque se afirma que é um direito inclusivo, o qual considera as pessoas pelo simples fato de serem seres humanos (VIAL, 2007). A proposta do Direito Fraterno é fornecer um novo olhar para o Direito, fundamentado na amizade, na ruptura da busca pela identidade e no pacto pela paz - o que não significa a ausência de conflitos. Ademais, não acredita na violência legítima, destitui o código dual do amigo-inimigo e acredita na jurisdição mínima e na adoção de meios menos violentos de tratamento de conflitos. "O Direito Fraterno busca resgatar um certo iluminismo, centrado na fraternidade. Esta nova proposta aponta para uma nova "luz", uma nova possibilidade de integração entre povos e nações, integração esta fundamentada no cosmopolitismo, onde as necessidades vitais são suprimidas pelo pacto jurado conjuntamente" (STURZA; ROCHA, 2016).

Assim, "a amizade reaparece nos sistemas sociais como diferença entre interação de identidades individuais, que se escolhem e orientam a comunicação voluntariamente, e as relações burocráticas e heterodirecionadas dos mecanismos dos grandes sistemas funcionais" (RESTA, 2004, p. 31). A peculiaridade do Direito Fraterno reside no fato de que a gratidão pelo reconhecimento de um amigo estabelece a mais consistente solidariedade que fundamenta o sistema social, sendo capaz de formar vínculos atemporais, enquanto que ao findar o circuito da amizade, encontra-se lugar para o inimigo. No entendimento de Resta, o si mesmo da humanidade é o lugar da ambivalência, que edifica e destrói; que ama e odeia; que vive de solidariedades e prepotências, de amizades e inimizades, tudo simultaneamente.

\footnotetext{
${ }^{12}$ Para Resta (2004, p. 54), "o Direito Fraterno coloca, pois, em evidência toda a determinação histórica do direito fechado na angústia dos confins estatais e coincide com o espaço de reflexão ligado ao tema dos Direitos Humanos, com uma consciência a mais: a de que a humanidade é simplesmente o lugar "comum", somente em cujo interior pode-se pensar o reconhecimento e a tutela. [...] os Direitos Humanos são aqueles direitos que somente podem ser ameaçados pela própria humanidade, mas que não podem encontrar vigor, também aqui, senão graças à própria humanidade. Bastaria, para tanto, escavar na fenda profunda que corre entre duas diferentes expressões como "ser homem" e "ter humanidade". Ser homem não garante que se possua aquele sentimento singular de humanidade".
} 
Da guerra somente advém o vazio do luto e a elaboração da dor. Nesse sentido, verificase que ser amigo da humanidade é participar dos destinos dos homens movido por uma ideia, ter respeito por qualquer outro e por si mesmo, possuir sensibilidade, dever e responsabilidade, visto que a humanidade é termo inclusivo, é o lugar-comum das diferenças, pois contém, ao mesmo tempo, amizade e inimizade.

Vislumbra-se, a partir do exposto, que a sociedade apresenta uma necessidade de insistir nos códigos fraternos e tentar valorizar possibilidades diferentes, eis que a fraternidade retoma a comunhão de pactos entre diferentes sujeitos concretos, com suas histórias e suas diferenças. $\mathrm{O}$ Direito Fraterno é, pois, um direito jurado, em conjunto, por irmãos, homens e mulheres, com um pacto em que se 'decide compartilhar' regras mínimas de convivência. Dessarte, o olhar de Resta é, antes de tudo, um olhar para os direitos humanos. Não há espaço para etnocentrismo e por isso o Direito Fraterno é cosmopolita (pois reporta ao cósmico, ao valor universal dos direitos humanos, e não à lógica mercantilista). Não é violento, pois se pauta na mediação (ideia de jurisdição mínima). É inclusivo, visto que escolhe os direitos fundamentais e define o acesso universalmente compartilhado, onde todos podem gozar, e não somente uma minoria (RESTA, 2004). Ou seja, fundamenta-se no processo comunicacional, no diálogo e consenso, bem como no respeito absoluto aos direitos humanos e na dignidade de pessoa humana, revelando-se, portanto, preconizador do Estado Democrático de Direito e assecuratório de seus princípios e valores.

Compreende-se, portanto, que o Direito Fraterno é um direito jurado, cujas regras existem e devem ser consideradas, mas no sentido do que é de todos os seres humanos. O Direito Fraterno é inclusivo e defende os direitos fundamentais ao pautar-se pelo acesso universalmente compartilhado, onde todos gozam de forma igual da condição de seres humanos.

Nesse sentido, insere-se a perspectiva do Direito Fraterno enquanto reconhecimento do outro, defendendo-se que os seres humanos, enquanto amigos da humanidade, são indivíduos morais e racionais que, de forma consciente, conhecem os riscos, mas apostam na existência de um bem comum. A defesa dos direitos humanos, bem como a sua violação, somente pode ser feita dentro da própria humanidade, razão pela qual somente ela pode ameaçar a si mesma, o que justifica abordá-la a partir de uma ideia pacificadora expressa na fraternidade.

\section{CONCLUSÃO}

A presente pesquisa teve como escopo o estudo do estrangeiro na contemporaneidade sob a ótica do Direito Fraterno enquanto expressão dos Direitos Humanos, apresentando, a partir do método de abordagem dedutivo, a hipótese da metateoria do Direito Fraterno para viabilizar a recepção do estrangeiro como amigo da humanidade. Nesse sentido, discorreu-se acerca do processo migratório em um cenário de mudanças políticas, econômicas, sociais e culturais para, então, em um segundo momento, abordar-se o estrangeiro e o nacional enquanto seres humanos iguais, sem qualquer distinção, o que justifica, na sequência, o reconhecimento da fraternidade enquanto elo da humanidade para concretização e garantia dos Direitos Humanos.

A maximização das correntes migratórias, em tempos de globalização e avanços tecnológicos, é uma realidade. Países desenvolvidos, em razão de suas características territoriais, econômicas, políticas e culturais, recebem um fluxo contínuo de entrada de estrangeiros, os quais, além de propiciarem as mais variadas contribuições à sociedade, também são portadores de necessidades e direitos, especialmente aqueles que proporcionem reconhecimento mínimo.

A invisibilidade do estrangeiro no âmbito de um país diverso de sua origem não decorre da ausência de diretrizes jurídicas para tanto, pois elas são claras e devem ser interpretadas à luz dos princípios da dignidade humana e igualdade. É da dignidade humana - que não pode ser reconhecida somente aos nacionais - que se extrai a essência de todos os Direitos Humanos, inclusive o Direito Fraterno, os quais devem ser garantidos, indistintamente, a todos, sejam nacionais ou estrangeiros. 
Em outras palavras, acolher seres humanos vindos de outra quadra e especialmente em situação de vulnerabilidade, é exemplo de quem se preocupa para além das linhas divisórias de um Estado, com a condição humana, uma vez que razões de ordem legal, ética e humanitária sustentam o entendimento de que os estrangeiros residentes ou de passagem são merecedores de atenção. Significa, portanto, sustentar o reconhecimento do outro pela prática da alteridade e, ao fazê-lo, não somente se permite que sua história seja contada e sua identidade preservada, mas, também, sua condição de ser humano garantida. A defesa do agir fraterno transcende aos limites territoriais e permite que os Estados, ao receberem estrangeiros como iguais, corroborem com a evolução dos homens para uma sociedade mais justa, mais igual e mais fraterna, o que confirma a hipótese inicial e atende ao objetivo proposto pela pesquisa.

\section{REFERÊNCIAS BIBLIOGRÁFICAS}

BAUMAN, Zygmunt; MAURO, Ezio. Babel: entre a incerteza e a esperança. Trad. Renato Aguiar. 1. ed. Rio de Janeiro: Zahar, 2016.

BAUMAN, Zygmunt. Estranhos à nossa porta. Trad. Carlos Alberto Medeiros. 1. ed. Rio de Janeiro: Zahar, 2017.

. O mal-estar da pós-modernidade. Rio de Janeiro: Zahar, 1997.

BOBBIO, Norberto. A era dos direitos. Rio de Janeiro: Editora Campos, 1992.

BRZOZOWSKI, Jan. Migração internacional e desenvolvimento econômico. Estudos Avançados, v. 26, n. 75, p. 137-156. Disponível em: 〈www.scielo.br/pdf/ea/v26n75/09.pdf> Acesso em: 08 ago. 2017.

CALETTI, Leandro; STAFFEN, Márcio Ricardo. Da necessidade de uma universalidade rediviva para os Direitos Humanos. In: Revista de Direito Brasileira. v. 16. n. 7. São Paulo: Jan./Abr. 2017. p. 96-114.

CAMPUZANO-JULIOS, Afonso de; SANTOS, André Leonardo Copetti; LUCAS, Doglas Cesar. Direitos Humanos, imigração e diversidade: dilemas de vida em movimento na sociedade contemporânea. Ijuí: Ed. Unijuí, 2016.

COMPARATO, Fábio Konder. A afirmação histórica dos Direitos Humanos. São Paulo: Saraiva, 1999.

COMISSÃO GLOBAL SOBRE MIGRAÇÕES INTERNACIONAIS. Migration in Interconnected World: new directions for action. Genebra: CGMI, 2005. Disponível em: <http://www.gcim.org/> Acesso em: 09 ago. 2017.

ELIAS, Norbert; SCOTSON L. John. Os estabelecidos e os Outsiders. Sociologia das relações de poder a partir de uma pequena comunidade. Trad. Vera Ribeiro. Rio de Janeiro: Jorge Zahar Editor, 2000.

EINSTEIN, Albert; FREUD, Sigmund. Um diálogo entre Einstein e Freud - por que a guerra? Santa Maria: FADISMA, 2005.

FARIA, Maria Rita Fontes. Migrações internacionais no plano multilateral: reflexões para política externa brasileira. Brasília: FUNAG, 2015. 
GALLI, Carlo. La humanidad multicultural. Trad. Juan Ramón Azaola. Buenos Aires: Katz Editores, 2010.

GIDDENS, Anthony. Mundo em descontrole: o que a globalização está fazendo de nós. Rio de Janeiro: Record, 2010.

IANNI, Octavio. A sociedade global. 4. ed. Rio de Janeiro: Civilização Brasileira, 1996.

A era do globalismo. 7. ed. Rio de Janeiro: Civilização Brasileira, 2002.

INTERNATIONAL ORGANIZATION FOR MIGRATION, World Migration Report 2015. Migrants and Cities: New Partnerships to Manage Mobilitt. Genebra: OIM, 2015. Disponível em: <https://www.iom.int/world-migration-report-2015> Acesso em: 09 ago. 2017.

Disponível

Fatal Journeys Trackink. Live Lost during Migration. Genebra: OIM, 2014. em: $\langle$ https://publications.iom.int/system/files/pdf/fataljourneys_countingtheuncounted.pdf $>$ Acesso em: 09 ago. 2017.

MAZZUOLI, Valerio de Oliveira. Curso de Direito Internacional Público. 5. ed., atual e ampl. São Paulo: Editora Revista dos Tribunais, 2011.

MENEZES, Frederico Lucena de. Migração: uma perspectiva psicológica, uma leitura pósmoderna ou, simplesmente, uma visão preconceituosa. In: CUNHA, Maria Jandyra Cavalcanti [et al]. Migração e identidade: olhares sobre o tema. São Paulo: Centauro, 2007.

NEVES, Marcelo. Transconstitucionalismo. São Paulo: Editora WMF Martins, 2013.

RESTA, Eligio. Direito Fraterno. Santa Cruz do Sul: EDUNISC, 2004.

SANTOS, André Leonardo Copetti; LUCAS, Doglas Cesar. A (in)diferença no direito. Porto Alegre: Livraria do Advogado, 2015.

SOARES, Guido Fernando Silva. Os direitos humanos e a proteção dos estrangeiros. Revista da Faculdade de Direito de São Paulo, São Paulo, v. 99, p. 403-460, 2004. Disponível em: <https://www.revistas.usp.br/rfdusp/article/view/67631> Acesso em: 10 ago. 2017.

SPENGLER, Fabiana Marion. Fundamentos Políticas da Mediação Comunitária. Ijuí: Ed. Unijuí, 2012.

STURZA, Janaina Machado; ROCHA, Claudine Rodembusch. Direito e Fraternidade: paradigmas para a construção de uma nova sociedade. Disponível em: http://publicadireito.com.br/artigos/?cod=601c6bc71c748001 Acesso em: 23 set. 2016.

STURZA, Janaina Machado; MARTINI, Sandra Regina. As Dimensões da Sociedade através da Metateoria do Direito Fraterno: um espaço para a analise do direito à saúde. In: Revista de Sociologia, Antropologia e Cultura Jurídica. v. 2. n. 2. Curitiba, Jul/Dez. 2016. p. 990-1008. 
TEDESCO, João Carlos. Estrangeiros, extracomunitários e transnacionais: paradoxos da alteridade nas migrações internacionais: brasileiros na Itália. Passo Fundo: Ed. Universidade de Passo Fundo, 2010.

VIAL, Sandra Regina Martini. Sociedade Complexa e o Direito Fraterno. In: SANTOS, André Leonardo Copetti; STRECK, Lenio Luiz; ROCHA, Leonel Severo et al. (Orgs.). Constituição, sistemas sociais e hermenêutica: programa de pós-graduação em Direito da UNISINOS: mestrado e doutorado. Porto Alegre: Livraria do Advogado Ed.; São Leopoldo: UNISINOS, 2007. 